\title{
Solvent-free microwave-assisted synthesis of oxadiazoles containing imidazole moiety
}

\author{
PRIYA V FRANK, K S GIRISH and BALAKRISHNA KALLURAYA \\ Department of Studies in Chemistry, Mangalore University, Mangalagangothri, Mangalore 574219 \\ e-mail: bkalluraya_2001@yahoo.com
}

MS received 24 July 2006; revised 25 January 2007

\begin{abstract}
Microwave-assisted as well as conventional synthesis of 5-substituted-2-(2-methyl-4-nitro-1imidazomethyl)-1,3,4-oxadiazoles containing the nitroimidazole moiety is carried out and their antibacterial, antifungal and anti-inflammatory activity is reported.
\end{abstract}

Keywords. Microwave synthesis; imidazole derivatives; 1,3,4-oxadiazoles; biological activity; antiinflammatory activity.

\section{Introduction}

Use of microwave technology in organic and inorganic reactions is reported in a number of publications and reviews. ${ }^{1-3}$ In the last few years, there has been increasing interest in the use of environmentally benign reagents and conditions ${ }^{4-6}$ particularly in solvent-free procedures. ${ }^{7}$ In dry media, reactions occur rapidly and the method avoids hazards associated with solvents especially in sealed vessels. The absence of solvent reduces reaction time and always improves yield. Using microwaves with proper control of power and reaction temperature is more efficient than conventional heating. In this context, we planned to prepare oxadiazoles under eco-friendly and environmentally benign solvent-free conditions, wherein several disadvantages like long reaction time and tedious work-up can be overcome.

The imidazole nucleus appears in a number of naturally occurring products like the amino acids, histidine and purines which comprise many of the most important bases in nucleic acids. Imidazole derivatives possess a broad spectrum of pharmacological activities such as anticonvulsant, ${ }^{8}$ anti-parkinson ${ }^{9}$ and monoamineoxidase (MAO) inhibitory ${ }^{10}$ activity.

The oxadiazole chemistry has been developed extensively and is still developing. Presently there are a number of drugs used clinically, which comprise oxadiazole moiety in association with various heterocyclic rings. In view of these, a project was un-

*For correspondence dertaken to synthesise a new series of 1,3,4-oxadiazoles containing the 4-nitroimidazole moiety by microwave irradiation and to evaluate the new compounds for their pharmacological activity.

\section{Results and discussion}

The starting material 2-methyl-4-nitro-imidazole ${ }^{11} \mathbf{1}$ employed in the preparation of hydrazide $\mathbf{3}$ is obtained commercially and is used after purification by recrystallization. Ethylchloroacetate $\mathbf{2}$ was procured from Ranbaxy and was purified by distillation. The imidazole hydrazide $\mathbf{3}$ was obtained by refluxing the starting material $\mathbf{1}$ with ethylchloroacetate in dry acetone in the presence of potassium carbonate and subsequent hydrazinolysis with hydrazine hydrate (scheme 1).

The aryloxy acetic acids $\mathbf{5 a - e}$ were prepared according to the method reported in the literature by the reaction of phenols with chloroacetic acid employing sodium hydroxide base and subsequent neutralization with hydrochloric acid (scheme 2) and were identified by their sharp melting point and reference to literature ${ }^{12}$. The characterization data of these newly synthesized aryloxyacetic acids are given in table 1.

The 5-aryl-2-(2-methyl-4-nitro-1-imidazomethyl)1,3,4-oxadiazoles $\mathbf{7 a - 1}$ were prepared by the microwave irradiation of 2-methyl-4-nitro-1-imidazo acethydrazide 4 with appropriate carboxylic acids in the presence of phosphorous oxy chloride (scheme 3). Similarly, the reaction was also carried out by the 


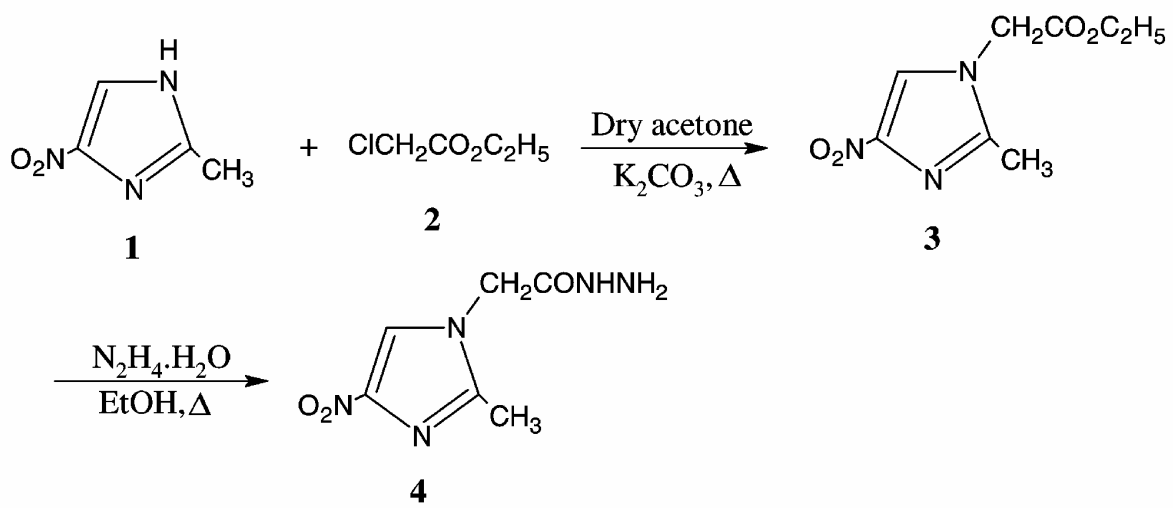

Scheme 1.

Table 1. Physical and analytical data of compounds 5a-e.

\begin{tabular}{lcccc}
\hline Compound & Ar & Melting point $\left({ }^{\circ} \mathrm{C}\right)$ & Yield (\%) & Molecular formula \\
\hline $\mathbf{5 a}$ & Phenyl & $97-99$ & 80 & $\mathrm{C}_{8} \mathrm{H}_{8} \mathrm{O}_{3}$ \\
$\mathbf{5 b}$ & $p$-Tolyl & $150-152$ & 63 & $\mathrm{C}_{9} \mathrm{H}_{10} \mathrm{O}_{3}$ \\
$\mathbf{5 c}$ & $o$-Tolyl & $141-142$ & 77 & $\mathrm{C}_{9} \mathrm{H}_{10} \mathrm{O}_{3}$ \\
$\mathbf{5 d}$ & $p$-Chlorophenyl & $155-157$ & 62 & $\mathrm{C}_{8} \mathrm{H}_{7} \mathrm{ClO}_{3}$ \\
$\mathbf{5 e}$ & $p$-Chloro- $m$-tolyl & $176-178$ & 70 & $\mathrm{C}_{9} \mathrm{H}_{9} \mathrm{ClO}_{3}$ \\
\hline
\end{tabular}

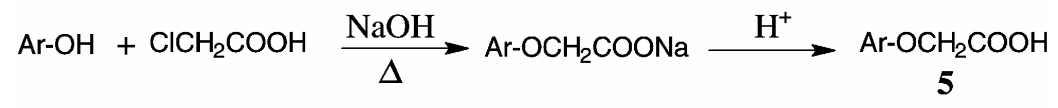

5a: $\mathrm{Ar}=\mathrm{C}_{6} \mathrm{H}_{5}$

5b: $\mathrm{Ar}=4-\mathrm{CH}_{3} \mathrm{C}_{6} \mathrm{H}_{4}$ 5c: $\mathrm{Ar}=2-\mathrm{CH}_{3} \mathrm{C}_{6} \mathrm{H}_{4}$ 5d: $\mathrm{Ar}=4-\mathrm{ClC}_{6} \mathrm{H}_{4}$

5e: $\mathrm{Ar}=4-\mathrm{Cl}-2-\mathrm{CH}_{3}-\mathrm{C}_{6} \mathrm{H}_{3}$

Scheme 2.<smiles>Cc1nc([N+](=O)[O-])cn1CC(N)=O</smiles>

7a: $\mathrm{R}=\mathrm{C}_{6} \mathrm{H}_{5}$

7b: $\mathrm{R}=4-\mathrm{CH}_{3} \mathrm{C}_{6} \mathrm{H}_{4}$

7c: $\mathrm{R}=4-\mathrm{OCH}_{3} \mathrm{C}_{6} \mathrm{H}_{4}$

7d: $\mathrm{R}=4-\mathrm{ClC}_{6} \mathrm{H}_{4}$

7e: $\mathrm{R}=2-\mathrm{CH}_{3} \mathrm{C}_{6} \mathrm{H}_{4}$

7f: $\mathrm{R}=\mathrm{C}_{5} \mathrm{H}_{4} \mathrm{~N}$

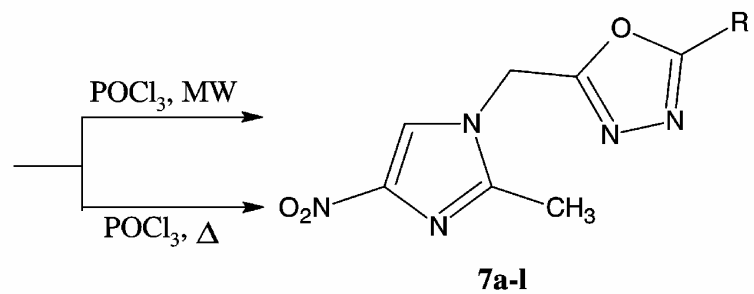

$7 \mathrm{~g}: \mathrm{R}=2-\mathrm{C}_{4} \mathrm{H}_{3} \mathrm{O}$

7h: $\mathrm{R}=\mathrm{C}_{6} \mathrm{H}_{5}-\mathrm{OCH}_{2}$

7i: $\mathrm{R}=4-\mathrm{CH}_{3}-\mathrm{C}_{6} \mathrm{H}_{4}-\mathrm{OCH}_{2}$

7j: $\mathrm{R}=2-\mathrm{CH}_{3}-\mathrm{C}_{6} \mathrm{H}_{4}-\mathrm{OCH}_{2}$

7k: $\mathrm{R}=4-\mathrm{Cl}-\mathrm{C}_{6} \mathrm{H}_{4}-\mathrm{OCH}_{2}$

7l: $\mathrm{R}=4-\mathrm{Cl}-2-\mathrm{CH}_{3}-\mathrm{C}_{6} \mathrm{H}_{3}-\mathrm{OCH}_{2}$

Scheme 3. 
conventional method by refluxing an intimate mixture of hydrazide 4 with appropriate carboxylic acid in phosphorous oxy chloride in an oil bath. The physical constants, yield and analytical data of 5-substituted2-(2-methyl-4-nitro-1-imidazomethyl)-1,3,4-oxadiazoles $\mathbf{7 a - 1}$ are given in table 2 .

\section{Biological activity}

\subsection{Antibacterial activity}

Studies on the antibacterial activity of synthesized compounds 7 have been carried out against four pathogenic organisms, viz., Staphylococcus aureus $\left(\mathrm{G}^{+}\right)$, Klebsiella pneumoniae $\left(\mathrm{G}^{-}\right)$, Escherichia coli $\left(\mathrm{G}^{-}\right)$and Pseudomonas aeruginosa $\left(\mathrm{G}^{-}\right)$. The antibacterial activity of the newly synthesized compounds in the present investigation was assessed by the cup-plate method. ${ }^{13}$ The results of the antibacterial studies are shown in table 3. Among the compounds tested, $\mathbf{7 e}$ and $\mathbf{7 l}$ showed good activity against the bacteria E. coli, $P$. aeruginosa and $K$. pneumoniae and moderate activity against $S$. aureus.
Compound $\mathbf{7 h}$ showed good activity against $E$. coli and $P$. aeruginosa and moderate activity against $K$. pneumoniae and $S$. aureus. Compound $7 \mathbf{i}$ showed good activity against $P$. aeruginosa and $K$. pneumoniae and moderate activity against $S$. aureus. Compound $7 \mathbf{j}$ showed good activity against $K$. pneumoniae and moderate activity against $S$. aureus.

\subsection{Antifungal activity}

The antifungal activity studies of the newly synthesized oxadiazole derivatives have been carried out against the fungi Aspergillus flavus, A. fumigatus, Penicillium and Trichophyton by the cup-plate method. ${ }^{13}$ The results of the antifungal studies are shown in table 4 . Among the compounds tested, 7d showed good activity against all the fungi. Compound 7f showed good activity against the fungi A. flavus and Penicillium. Compounds $\mathbf{7 b}$ and $\mathbf{7 c}$ showed good activity against the fungus $A$. flavus and moderate activity against Penicillium. Compound $\mathbf{7} \mathbf{j}$ showed good activity against the fungus $A$. fumigatus and moderate activity against Trichophyton,

Table 2. Physical and analytical data of compounds 7a-l.

\begin{tabular}{|c|c|c|c|c|c|c|c|c|}
\hline \multirow[b]{2}{*}{ Compd } & \multirow[b]{2}{*}{$\mathrm{R}$} & \multirow{2}{*}{$\begin{array}{l}\text { Melting } \\
\text { point } \\
\left({ }^{\circ} \mathrm{C}\right)\end{array}$} & \multirow{2}{*}{$\begin{array}{l}\text { (\%) Yield } \\
\text { microwave } \\
\text { (traditional) }\end{array}$} & \multirow{2}{*}{$\begin{array}{l}\text { Time } \\
\text { (min) }\end{array}$} & \multirow{2}{*}{$\begin{array}{l}\text { Molecular } \\
\text { formula }\end{array}$} & \multicolumn{3}{|c|}{$\begin{array}{l}\text { Elemental analysis } \\
\text { Found (calculated) (\%) }\end{array}$} \\
\hline & & & & & & $\mathrm{C}$ & $\mathrm{H}$ & $\mathrm{N}$ \\
\hline $7 a$ & Phenyl & 174 & $66(56)$ & $1 \cdot 5$ & $\mathrm{C}_{13} \mathrm{H}_{11} \mathrm{~N}_{5} \mathrm{O}_{3}$ & $\begin{array}{c}54.52 \\
(54 \cdot 74)\end{array}$ & $\begin{array}{c}3 \cdot 91 \\
(3 \cdot 86)\end{array}$ & $\begin{array}{c}24 \cdot 62 \\
(24 \cdot 56)\end{array}$ \\
\hline $7 \mathbf{b}$ & $p$-Tolyl & 164 & $65(50)$ & 3 & $\mathrm{C}_{14} \mathrm{H}_{13} \mathrm{~N}_{5} \mathrm{O}_{3}$ & $\begin{array}{c}56 \cdot 28 \\
(56 \cdot 19)\end{array}$ & $\begin{array}{c}4 \cdot 29 \\
(4 \cdot 35)\end{array}$ & $\begin{array}{c}23.50 \\
(23 \cdot 41)\end{array}$ \\
\hline 7c & p-Anisyl & 172 & $54(40)$ & 2 & $\mathrm{C}_{14} \mathrm{H}_{13} \mathrm{~N}_{5} \mathrm{O}_{4}$ & $\begin{array}{c}53.42 \\
(53.33)\end{array}$ & $\begin{array}{c}4 \cdot 08 \\
(4 \cdot 13)\end{array}$ & $\begin{array}{c}22 \cdot 31 \\
(22 \cdot 22)\end{array}$ \\
\hline $7 d$ & p-Chlorophenyl & 212 & $56(50)$ & 4 & $\mathrm{C}_{13} \mathrm{H}_{10} \mathrm{~N}_{5} \mathrm{O}_{3} \mathrm{Cl}$ & $\begin{array}{c}48 \cdot 99 \\
(48 \cdot 90)\end{array}$ & $\begin{array}{l}3 \cdot 05 \\
(3 \cdot 13)\end{array}$ & $\begin{array}{r}21 \cdot 86 \\
(21 \cdot 94)\end{array}$ \\
\hline $7 e$ & $o$-Tolyl & 157 & $67(55)$ & 2 & $\mathrm{C}_{14} \mathrm{H}_{13} \mathrm{~N}_{5} \mathrm{O}_{3}$ & $\begin{array}{c}56 \cdot 25 \\
(56 \cdot 19)\end{array}$ & $\begin{array}{c}4 \cdot 29 \\
(4 \cdot 35)\end{array}$ & $\begin{array}{c}23 \cdot 36 \\
(23 \cdot 41)\end{array}$ \\
\hline $7 f$ & 3-Pyridyl & 269 & $63(55)$ & 2 & $\mathrm{C}_{12} \mathrm{H}_{10} \mathrm{~N}_{6} \mathrm{O}_{3}$ & $\begin{array}{c}50.41 \\
(50.35)\end{array}$ & $\begin{array}{c}3.55 \\
(3 \cdot 49)\end{array}$ & $\begin{array}{c}29 \cdot 28 \\
(29 \cdot 37)\end{array}$ \\
\hline $7 \mathrm{~g}$ & 2-Furyl & 247 & $66(48)$ & 2 & $\mathrm{C}_{11} \mathrm{H}_{9} \mathrm{~N}_{5} \mathrm{O}_{4}$ & $\begin{array}{c}48 \cdot 11 \\
(48 \cdot 00)\end{array}$ & $\begin{array}{l}3 \cdot 33 \\
(3 \cdot 27)\end{array}$ & $\begin{array}{c}25 \cdot 36 \\
(25 \cdot 45)\end{array}$ \\
\hline $7 \mathbf{h}$ & p-Phenoxy methyl & 207 & $75(60)$ & 5 & $\mathrm{C}_{14} \mathrm{H}_{13} \mathrm{~N}_{5} \mathrm{O}_{4}$ & $\begin{array}{c}53.42 \\
(53 \cdot 33)\end{array}$ & $\begin{array}{l}4 \cdot 09 \\
(4 \cdot 13)\end{array}$ & $\begin{array}{l}22 \cdot 16 \\
(22 \cdot 22)\end{array}$ \\
\hline $7 \mathbf{i}$ & p-Cresyloxy methyl & 201 & $75(62)$ & 5 & $\mathrm{C}_{15} \mathrm{H}_{15} \mathrm{~N}_{5} \mathrm{O}_{4}$ & $\begin{array}{c}54.65 \\
(54.71)\end{array}$ & $\begin{array}{c}4.62 \\
(4.56)\end{array}$ & $\begin{array}{c}21 \cdot 19 \\
(21 \cdot 18)\end{array}$ \\
\hline $7 \mathbf{j}$ & $o$-Cresyloxy methyl & 249 & $71(54)$ & 5 & $\mathrm{C}_{15} \mathrm{H}_{15} \mathrm{~N}_{5} \mathrm{O}_{4}$ & $\begin{array}{c}54 \cdot 66 \\
(54.71)\end{array}$ & $\begin{array}{c}4 \cdot 49 \\
(4 \cdot 56)\end{array}$ & $\begin{array}{c}21 \cdot 35 \\
(21 \cdot 28)\end{array}$ \\
\hline $7 \mathbf{k}$ & p-Chloro-phenoxymethyl & 234 & $75(62)$ & 4 & $\mathrm{C}_{14} \mathrm{H}_{12} \mathrm{~N}_{5} \mathrm{O}_{4} \mathrm{Cl}$ & $\begin{array}{c}48.09 \\
(48 \cdot 14)\end{array}$ & $\begin{array}{c}3.49 \\
(3.44)\end{array}$ & $\begin{array}{c}20 \cdot 11 \\
(20 \cdot 06)\end{array}$ \\
\hline 71 & $p$-Chloro-m-cresyloxy methyl & 239 & $68(52)$ & 5 & $\mathrm{C}_{15} \mathrm{H}_{14} \mathrm{~N}_{5} \mathrm{O}_{4} \mathrm{Cl}$ & $\begin{array}{c}49.65 \\
(49.59)\end{array}$ & $\begin{array}{c}3 \cdot 93 \\
(3 \cdot 86)\end{array}$ & $\begin{array}{c}19 \cdot 20 \\
(19 \cdot 28)\end{array}$ \\
\hline
\end{tabular}

Solvent of crystallization: DMF + ethanol 
Table 3. Antibacterial screening for compounds 7.

\begin{tabular}{lcccc}
\hline & \multicolumn{4}{c}{ Diameter of zone of inhibition $(\mathrm{mm})$ at $10 \mathrm{mg} / \mathrm{ml}$ concentration } \\
\cline { 2 - 5 } Compd & E. coli & P. aeruginosa & K. pneumoniae & S. aureus \\
\hline 7b & - & - & - & - \\
7d & - & - & - & - \\
7e & 25 & 28 & 26 & 18 \\
7f & - & - & - & - \\
7h & 25 & 24 & 12 & 12 \\
7i & - & 28 & 28 & 16 \\
7j & - & - & 26 & 14 \\
7k & - & - & - & - \\
7l & 24 & 26 & 26 & 15 \\
Ciprofloxacin (std)* & 20 & 22 & 22 & - \\
Solvent control (DMF) & - & - & - & 20 \\
\hline
\end{tabular}

*std $=$ standard

Table 4. Antifungal screening for compounds 7.

\begin{tabular}{lcccc}
\hline & \multicolumn{4}{c}{ Diameter of zone of inhibition (mm) at $10 \mathrm{mg} / \mathrm{mL}$ concentration } \\
\cline { 2 - 5 } Compd & A. flavus & A. fumigatus & Penicillium & Trichophyton \\
\hline 7b & 26 & - & 14 & - \\
7c & 28 & - & 18 & - \\
7d & 28 & 26 & 28 & 28 \\
7e & - & - & - & - \\
7f & 26 & - & 26 & - \\
7g & - & - & 12 & - \\
7i & - & - & - & 12 \\
7j & - & 24 & - & 14 \\
7l & - & - & - & - \\
Ciclopiroxolamine (std)* & 22 & 22 & 20 & 20 \\
Solvent control (DMF) & - & - & - & - \\
\hline
\end{tabular}

*std = standard

whereas compounds $\mathbf{7 g}$ and $\mathbf{7 i}$ showed moderate activity against the fungi Penicillium and Trichophyton respectively.

\subsection{Anti-inflammatory activity}

The method of Winter et $a l^{14}$ was followed to study the anti-inflammatory activity of the oxadiazoles with slight modification. Formalin-induced oedema test was employed. The rat paw volume was measured by using the apparatus of Buttle et $a l^{15}$, which was again modified by Singh and Ghosh. ${ }^{16}$ The results obtained are represented in table 5 . All the tested compounds have anti-inflammatory activity at a dose of $50 \mathrm{mg} / \mathrm{kg}$. The anti-inflammatory activity of $\mathbf{7 b}, \mathbf{7 c}$ and $\mathbf{7 d}$ is comparable to that of indomethacin at a dose of $1.5 \mathrm{mg} / \mathrm{kg}$.

\section{Experimental section}

\subsection{General}

All reagents and solvents were procured from Ranbaxy. The reactions were carried out under microwave irradiation at $160 \mathrm{~W}$. TLC was used to monitor the progress of the reaction. The melting points of the newly synthesised compounds were determined in open capillaries and are uncorrected. The IR spectra were recorded on a Perkin-Elmer 983 IR spectrophotometer or Jasco FT IR 430 spectrophotometer as $\mathrm{KBr}$ pellet. The ${ }^{1} \mathrm{H}$-NMR spectra were recorded on a Bruker AC 300F (300 MHz) NMR spectrometer using DMSO- $d_{6}$ or $\mathrm{CDCl}_{3}$ as solvent and TMS as internal standard. All chemical shift values are expressed in the $\delta$ scale downfield from TMS and proton signals are indicated as $s=$ singlet, $d=$ doublet, 
Table 5. Anti-inflammatory screening for compounds 7.

\begin{tabular}{|c|c|c|c|}
\hline \multirow[b]{2}{*}{ Compd } & \multirow[b]{2}{*}{ Dose (mg/kg) } & \multirow{2}{*}{$\frac{\text { Paw volume }(\mathrm{mL}) \text { after }}{3 \mathrm{~h}}$} & \multirow{2}{*}{$\frac{\text { Percentage inhibition of oedema after }}{3 \mathrm{~h}}$} \\
\hline & & & \\
\hline $7 \mathbf{b}$ & 50 & $0 \cdot 29$ & 50 \\
\hline $7 c$ & 50 & $0 \cdot 23$ & 60 \\
\hline $7 d$ & 50 & $0 \cdot 26$ & 55 \\
\hline $7 e$ & 50 & $0 \cdot 36$ & 38 \\
\hline $7 \mathbf{j}$ & 50 & $0 \cdot 39$ & 33 \\
\hline Control & $10 \mathrm{ml} / \mathrm{kg}$ & 0.58 & - \\
\hline Standard & $1 \cdot 5$ & $0 \cdot 20$ & 65 \\
\hline
\end{tabular}

$t=$ triplet, $m=$ multiplet. Mass spectra of the compounds were recorded on a Jeol JMS-D300 mass spectrometer by operating at $70 \mathrm{eV}$.

\subsection{2-Methyl-4-nitro-1-imidazo-ethylacetate (3)}

A mixture of 2-methyl-4-nitro-imidazole 1 (127 g, $1 \mathrm{~mol}$ ), ethyl chloroacetate 2 (122 g, $1 \mathrm{~mol}$ ) and potassium carbonate $(147 \mathrm{~g}, 1.5 \mathrm{~mol})$ in dry acetone $(500 \mathrm{~mL})$ was refluxed for $50 \mathrm{~h}$. The reaction mixture was filtered hot and the solvent was distilled off from the filtrate. The crude ester thus obtained was purified by recrystallization from ethanol, m.p. $96^{\circ} \mathrm{C}$ (lit. ${ }^{17}$ m.p. $95^{\circ} \mathrm{C}$ ), yield 106 g (50\%).

\subsection{2-Methyl-4-nitro-1-imidazo-acethydrazide (4)}

A mixture of 2-methyl-4-nitro-1-imidazo-ethylacetate 3 (106 g, $0.5 \mathrm{~mol})$ and hydrazine hydrate $(99 \%$, $25 \mathrm{~g}, 0.5 \mathrm{~mol})$ in ethanol $(100 \mathrm{~mL})$ was refluxed for $8 \mathrm{~h}$. The solution on cooling gave a solid mass of hydrazide 4, which was collected by filtration, and recrystallized from ethanol, m.p. $189^{\circ} \mathrm{C}$, yield $107 \mathrm{~g}$ (54\%).

Analysis (found): C, 36.37; H, 4.29; N, 35.46\%; (calculated for $\mathrm{C}_{6} \mathrm{H}_{9} \mathrm{~N}_{5} \mathrm{O}_{3}$ ): C, 36.18; $\mathrm{H}, 4.52 ; \mathrm{N}$, $35 \cdot 18 \%$.

MS: m/z 199 (M+, 70), 183 (02), 168 (48), 153 (20), 141 (100), 111 (05).

\subsection{Aryloxy acetic acids (5a-e)}

To a mixture of appropriate phenol $(0.1 \mathrm{~mol})$ and $35 \mathrm{~mL}$ of $33 \%$ sodium hydroxide, in a round-bottom flask, $25 \mathrm{~mL}$ of $50 \%$ chloroacetic acid solution was added. Water was added if necessary to dissolve the salt of phenol. The flask is stoppered loosely and heated on a boiling water bath for an hour. It is cooled, diluted with $100 \mathrm{~mL}$ of water, acidified to congo red with dilute hydrochloric acid and extracted with $300 \mathrm{~mL}$ of ether. The ethereal extract was washed with water and the aryloxyacetic acid was extracted with sodium carbonate $(5 \%, 250 \mathrm{~mL})$ solution. The sodium carbonate extract was acidified with dilute hydrochloric acid to congo red, the crystals formed were collected and recrystallized from water or aqueous ethanol to yield $\mathbf{5 a - e . ~}$

\subsection{5-Substituted-2-(2-methyl-4-nitro-1- imidazomethyl)-1,3,4-oxadiazoles (7a-l)}

Method I: A mixture of substituted carboxylic acid $(0.01 \mathrm{~mol})$ and hydrazide $4(0.01 \mathrm{~mol})$ was ground in a mortar using a pestle for uniform mixing. This mixture was taken in a $50 \mathrm{~mL}$ beaker and 5-6 drops of phosphorous oxychloride was added. The beaker was kept inside a microwave oven operating at $160 \mathrm{~W}$ for about $5 \mathrm{~min}$. The completion of the reaction was checked by TLC. The product was poured to crushed ice. It was then neutralized by $5 \%$ sodium bicarbonate. The solid obtained was filtered, dried and recrystallized from a mixture of ethanol-DMF to give $\mathbf{7 a - 1}$.

Method II: To a mixture of substituted carboxylic acid $(0.01 \mathrm{~mol})$ and hydrazide $4(0.01 \mathrm{~mol})$, phosphorous oxychloride $(5 \mathrm{~mL})$ was added. The reaction mixture was refluxed for $4-5 \mathrm{~h}$ on an oil bath, the contents were cooled to room temperature and poured onto crushed ice. It was then neutralized by $5 \%$ sodium bicarbonate solution. The solid that separated was collected by filtration through a Büchner funnel and dried. Further purification was done by recrystallization from a mixture of ethanol- 
DMF to give 7a-l. A few typical compounds are described below.

\section{5-Phenyl-2-(2-methyl-4-nitro-1-imidazomethyl)-} 1,3,4-oxadiazoles (7a)

m.p.: $172-74^{\circ} \mathrm{C}$; yield: $56 \%$.

IR (KBr) $v_{\text {max }}$ : 2991-3066, 1598, 1506, $1328 \mathrm{~cm}^{-1}$.

${ }^{1} \mathrm{H}$ NMR $\left(\mathrm{CDCl}_{3}\right): \delta 2.46\left(\mathrm{~s}, 3 \mathrm{H}, \mathrm{CH}_{3}\right) ; 4.77(\mathrm{~s}, 2 \mathrm{H}$, $\left.\mathrm{NCH}_{2}\right) ; 7.61-8.00$ (m, 5H, ArH); 8.48 (s, $1 \mathrm{H}$, imidazole $\mathrm{H}$ ).

5-(2-Furyl)-2-(2-methyl-4-nitro-1-imidazomethyl)1,3,4-oxadiazoles $(\mathbf{7 g})$

m.p.: $246-48^{\circ} \mathrm{C}$; yield: $48 \%$.

IR (KBr) $v_{\max }: 2966-3051,1595,1508,1336 \mathrm{~cm}^{-1}$.

${ }^{1} \mathrm{H}$ NMR $\left(\mathrm{CDCl}_{3}\right): \delta 2 \cdot 32\left(\mathrm{~s}, 3 \mathrm{H}, \mathrm{CH}_{3}\right) ; 4.94(\mathrm{~s}, 2 \mathrm{H}$, $\left.\mathrm{NCH}_{2}\right) ; 8.32(\mathrm{~s}, 1 \mathrm{H}$, imidazole $\mathrm{H}) ; 6.65-6.68(\mathrm{~m}$, $1 \mathrm{H}$, furan-4H); 7.22-7.23 ( $m, 1 \mathrm{H}$, furan-3H); 7.9017.907 ( $m, 1 \mathrm{H}$, Furan-5H)

5-o-Cresyloxymethyl-2-(2-methyl-4-nitro-1imidazomethyl)-1,3,4-oxadiazoles (7j)

m.p.: $245-47^{\circ} \mathrm{C}$; yield: $54 \%$.

IR (KBr) $v_{\max }: 2958-3055,1625,1542,1334 \mathrm{~cm}^{-1}$.

${ }^{1} \mathrm{H}$ NMR $\left(\mathrm{CDCl}_{3}\right): \delta 2 \cdot 21\left(\mathrm{~s}, 3 \mathrm{H}, \mathrm{CH}_{3}\right) ; 2 \cdot 29(\mathrm{~s}, 3 \mathrm{H}$, $\mathrm{CH}_{3}$ protons of $o$-tolyl); $4.63\left(\mathrm{~s}, 2 \mathrm{H}, \mathrm{NCH}_{2}\right) ; 4.89(\mathrm{~s}$, $\left.2 \mathrm{H}, \mathrm{OCH}_{2}\right) ; 8 \cdot 30(s, 1 \mathrm{H}$, imidazole $\mathrm{H}) ; 6 \cdot 84-7 \cdot 15$ $(m, 4 \mathrm{H}, \mathrm{Ar}-\mathrm{H})$.

5-p-Chlorophenoxymethyl-2-(2-methyl-4-nitro-1imidazomethyl)-1,3,4-oxadiazoles (7k)

m.p.: $231-34^{\circ} \mathrm{C}$; yield: $62 \%$.

IR (KBr) $v_{\max }: 2922-3014,1542,1494,1332 \mathrm{~cm}^{-1}$.

${ }^{1} \mathrm{H}$ NMR $\left(\mathrm{CDCl}_{3}\right): \delta 2 \cdot 30\left(\mathrm{~s}, 3 \mathrm{H}, \mathrm{CH}_{3}\right) ; 4.63(\mathrm{~s}, 2 \mathrm{H}$, $\left.\mathrm{NCH}_{2}\right) ; 4.90\left(\mathrm{~s}, 2 \mathrm{H}, \mathrm{OCH}_{2}\right) ; 8.30(\mathrm{~s}, 1 \mathrm{H}$, imidazole $\mathrm{H}) ; 7 \cdot 00(d, 2 \mathrm{H}, \mathrm{Ar}-\mathrm{H}), 7 \cdot 34$ (d, 2H, Ar-H).

\section{Acknowledgments}

The authors thank the authorities of the Regional Sophisticated Instrumentation Centre, Indian Institute of Technology, Chennai and the Sophisticated Instrumentation Facility, Indian Institute of Science, Bangalore for spectral and analytical data.

\section{References}

1. Abramovitch R A 1991 Org. Prep. Proc. Int. 23685

2. Baghurst D R and Mingos D M P 1991 Chem. Soc. Rev. 201

3. Loupy A 1993 Spect. Anal. 17533

4. Clark J H, Cullen S R, Barlow S J and Bastock T W 1994 J. Chem. Soc., Perkin Trans. II 1117

5. Villemin D and Hammadi M 1996 Synth. Commun. 264337

6. Varma R S, Dahiya R and Saini R K 1997 Tetrahedron Lett. 3867029

7. Loupy A, Bram G and Sansoulet J 1992 New J. Chem. 16233

8. Verma M, Chaturvedi A K, Chowdhari A and Parmar S S 1974 J. Pharm. Sci. 631740

9. Naithani P K, Srivatsava V K, Barthwal J P, Saxena A K, Gupta T K and Shanker K 1989 Indian J. Chem. B28 299

10. Harfenist M, Saroka E F and Meckenzie G M $1978 \mathrm{~J}$. Med. Chem. 21405

11. Novikov S S, Khmel'nitskii L I, Lebedev O V, Sevast'yanova V V and Epishina L V 1970 Khim. Geterotsikl Soedin 4 503; 1970 Chem. Abstr. 73 $66491 \mathrm{z}$

12. Furniss B S, Hannford A J, Smith P W G and Tatchell A R 2005 Vogel's textbook of practical organic chemistry 5th edn, p. 1249

13. Seelay H W and Van Demark P J 1975 Microbes in action, A laboratory manual in microbiology 2nd edn, p. 55

14. Winter C E, Risley E A and Nuss G W 1962 Proc. Soc. Exp. Biol. Med. 111544

15. Buttle C A M, Arey P D D, Howard E W and Kellet D N 1957 Nature (London) 179629

16. Singh H and Ghosh M N 1968 J. Pharm. Pharmacol. 20316

17. May \& Baker Ltd Belg. 1965 Chem. Abstr. 639144 